\title{
Comparison of acceptability of tropical fruit mixed nectars by mean test and multivariate statistical analysis
}

\section{Comparação da aceitabilidade de néctares mistos de frutas tropicais por teste de médias e análise estatística multivariada}

\author{
Paulo Henrique Machado Sousa ${ }^{1 *}$; Afonso Mota Ramos²; Geraldo Arraes Maia ${ }^{1}$; \\ Edy Sousa Brito ${ }^{3}$; Deborah Santos Garruti ${ }^{3}$; Raimundo Wilane Figueiredo ${ }^{1}$
}

\begin{abstract}
Fruits are a rich source of nutrients and fruit juices are a popular way of consuming them. Development of mixed juices, where two or more fruit juices are blended to obtain a product that combines the nutritional value of fruits, has been encouraged by the food industry and well accepted by consumers. This work aimed to develop mixed nectars of tropical fruits (cashew apple, mango and acerola) and to compare the acceptability data by mean test and multivariate statistical analysis of hierarchic grouping and principal compounds. The tropical fruit nectars showed good acceptability, the formulations with higher mango and cashew and lower acerola contents the most accepted. The formulation with $12.25 \%$ cashew apple pulp, $21 \%$ mango pulp and $1.75 \%$ acerola pulp had the highest global evaluation score. However, it could be observed by the cluster analysis of consumers' data and posterior principal components analysis of these results a clearly segmentation of consumers.
\end{abstract}

Key words: Global impression, cashew apple, mango, acerola, consumers

\section{Resumo}

As frutas são fontes ricas de nutrientes e os sucos de frutas são formas mais populares de consumi-las. $\mathrm{O}$ desenvolvimento de sucos mistos, em que duas ou mais frutas são misturadas para se obter um produto que combina o valor nutricional das frutas, tem sido estimulado pela indústria de alimentos e bem aceita pelos consumidores. Este trabalho teve como objetivo desenvolver néctares mistos de frutas tropicais (caju, manga e acerola) e comparar os dados de aceitabilidade por teste de média e análises estatísticas multivariadas de agrupamento hierárquico e componentes principais. O resultado do teste de médias indicou uma maior aceitação para os néctares com maiores teores de manga e caju e menores teores de acerola. A formulação contendo $12,25 \%$ de polpa de caju, $21 \%$ de polpa de manga e $1,75 \%$ de polpa de acerola teve o maior escore na avaliação global. No entanto, pode ser observado pela análise de cluster de dados dos consumidores e posterior análise de componentes principais destes resultados claramente uma segmentação dos consumidores.

Palavras-chave: Impressão global, caju, manga, acerola, consumidores

\footnotetext{
${ }^{1}$ Profs. da Universidade Federal do Ceará, UFC, Fortaleza, CE. E-mail: phenriquemachado@gmail.com; gamaia@netbandalarga. com.br; figueira@ufc.br

${ }^{2}$ Prof. da Universidade Federal de Viçosa, UFV, Viçosa, MG. E-mail: amramos@ufv.br

${ }^{3}$ Pesquisadores, Embrapa Agroindústria Tropical, Fortaleza, CE. E-mail: edy@cnpat.embrapa.br; deborah@cnpat.embrapa.br

* Author for correspondence
} 


\section{Introduction}

There is a growing market for beverages made with mixed fruits, mainly tropical ones (PEREIRA et al., 2009). Mixed fruit beverages have a series of advantages, such as the possibility of combining different aromas and flavors and nutritional components (SOUSA et al., 2010). Cashew apple (Anacardium occidentale L.) is one of the fruits with the most expressive production in Brazil; however, less than $20 \%$ of its production is used by the fruit juice industry. This is often caused by the concentration of the harvesting season in three months, showing the importance of the agroindustry to add value to the final products. Cashew apple is rich in vitamin $\mathrm{C}$, carotenoids and phenolic compounds (BRITO et al., 2007; KUBO et al., 2006). Acerola (Malpighia emarginata D.C.), on the other way, has low sensory appeal and short fruit shelf-life but high nutritional value, mainly vitamin $\mathrm{C}$ and carotenoids, antioxidant pigments whose combination is responsible for the fruit red color (SOUSA et al., 2010; LIMA et al., 2005). Due to its excellent attractive color and taste combined with good nutritive and functional characteristics, mango (Mangifera indica L.) has gained great economic importance, ranking among the ten most planted cultures in the world (DEMBITSKY et al., 2011). Mangoes contain high levels of bioactive compounds as phenolic compounds and carotenoids (POOVARODOM et al., 2010).

It is important to mention that these fruits have great potential for the world juice industry. The main form of utilization of cashew apples is to process them into juice, but its high astringency tends to impair its acceptance. The formulation of mixed fruits nectars may be an efficient way of reducing this negative impact. Mangoes have also been used as components of mixed nectars, thanks to the high viscosity of their pulp and their exotic and much appreciated flavor (MOSTAFA; ABD-EL-HADY; ASKAR, 1997; RAMOS et al., 2004). Some authors have mentioned the possibility of using acerola juice as an enhancing agent for several vitamin $\mathrm{C}$ poor juices and nectars (FARAONI et al., 2012; SOUSA et al., 2010; LIMA et al., 2009; PEREIRA et al., 2009). Some authors (FARAONI et al., 2012; SOUSA et al., 2010; LIMA et al., 2009; SOUSA et al., 2007) have been carrying out studies to optimize fruit blends, applying affective sensory tests for this purpose. Evaluation by such tests is traditionally achieved by means of univariate variance and mean tests. However, the simple acceptance mean value, in the case of consumer categories with opposing preferences, makes one group cancel the result of the other, resulting in values that many times do not present significant difference. That is why individual data variability must also be considered and data structure should be analyzed. For this reason, the individual variability of data and its structure must also be considered; such analysis may be accomplished by the statistical method named Principal Components Analysis (PCA). In this case, evaluated criterions are identified as dimensions that occupy orthogonal positions in a graphic representation. Combined to variance analyses and mean tests, the PCA can complement the acceptance analyses of one product, explaining the consumer's preference which becomes valuable information.

Sometimes, the original experimental data may not have a suitable distribution for the analysis, difficult to extract useful information and understandings. Measurements in different units and variables with different variances are some reasons for these problems. In these cases an original data preprocessing can be valuable. The analysis by hierarchic grouping is an excellent tool for preliminary analysis of data (SHARAF et al., 1986; BEEBE; PELL; SEASHOLTZ, 1998), useful to determine the likeness between the objectives and to identify anomalous samples.

The grouping analysis (Cluster Analysis) has the objective to incorporate according to some criterion of classification a body of $t$ sample units (treatment, progenitors, individuals etc) in groups through the evaluation of $p$ variables in such way that homogeneity occur inside each group 
and heterogeneity between them (JOHNSON; WICHERN, 2002). The process of grouping involves basically two steps. The first is related with an estimation of one measure of dissimilarity between the treatments, and the second with the adoption of a technique of grouping for the group formation (QANNARI et al., 1997; DAHL; NAES, 2004). These results, when visualized through diagrams known as dendograms indicate similarity between samples, such as that a minor distance between points indicates larger similarity between them.

The aim of this work was to develop mixed nectars of tropical fruits (cashew apple, mango and acerola), to evaluate their acceptability by hierarchy grouping followed by analysis of the principal components and to compare the results obtained through the mean tests with the results observed through the multivariate data analysis.

\section{Material and Methods}

\section{Raw materials}

Cashew apple, mango and acerola pulps, freshly extracted and frozen were obtained from a local fruit processing plant (Fortaleza-CE-BRAZIL), with physicochemical characteristics presented in Table 1.

Table 1. Physicochemical characterization of the fruit pulps used in the experiment.

\begin{tabular}{lccc}
\hline \multirow{2}{*}{ Determinations } & \multicolumn{2}{c}{ Pulps } \\
\cline { 2 - 4 } & Cashew apple & Mango & Acerola \\
\hline pH & 3.92 & 3.55 & 3.54 \\
Soluble solids content (SS) ( ${ }^{\circ}$ Brix) & 16.0 & 14.0 & 5.5 \\
Titratable acidity (TA) $\left(\mathrm{g}\right.$ of citric acid $100 \mathrm{~mL}^{-1}$ ) & 0.8 & 0.9 & 0.9 \\
SS/TA ratio & 12.3 & 10.5 & 3.9 \\
\hline
\end{tabular}

Source: Elaboration of the authors.

\section{Elaboration of mixed nectars of tropical fruits}

Ten mixed nectars of tropical fruits were formulated (Table 2) with the following pulps content variations: cashew apple, 12.25-21\%; mango, $12.25-21 \%$ and acerola, $1.75-10.50 \%$. The proportions of juices in each treatment were defined according to a simplex mixture design, with 10 treatments (MYERS; MONTGOMERY, 2002). Since the sum of the proportions of a mixture has

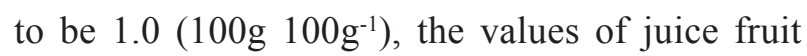
contents (whose sum was $35 \mathrm{~g}$ of juice $100 \mathrm{~g}^{-1}$ ) were normalized to make the sum equal to 1.00 . Acerola pulp was added in the lowest proportions, due to its limited sensory acceptance (SOUSA et al., 2010). The total pulp content in the final product was fixed in $35 \%$, the minimum established by Brazilian legislation for tropical juices (FAO/ WHO 2005). The fruit pulps were weighed, diluted in potable water, sucrose was added up to $11^{\circ}$ Brix and homogenized. The nectars were submitted to a heat treatment at $90^{\circ} \mathrm{C}$ for 60 seconds, hot filled in glass containers closed and then cooled in running water. 
Table 2. Simplex-centroid augmented designs with interior points in 10 treatments for the mixed fruit nectars formulations and results of Tukey test and rejection, indifference and acceptability percentage of mixed tropical fruit nectars.

\begin{tabular}{|c|c|c|c|c|c|c|c|}
\hline \multirow{2}{*}{ Treatment } & \multicolumn{3}{|c|}{ Pulp proportions (\%) } & \multirow{2}{*}{$\begin{array}{c}\text { Acceptance } \\
\text { score* }\end{array}$} & \multicolumn{3}{|c|}{ Frequency distribution $(\%)^{* *}$} \\
\hline & Cashew apple & Mango & Acerola & & Rejection & Indiference & Aceitability \\
\hline 1 & 21.00 & 12.25 & 1.75 & $7.4^{\mathrm{ab}}$ & 5 & 4 & 91 \\
\hline 2 & 12.25 & 21.00 & 1.75 & $7.7^{\mathrm{a}}$ & 4 & 0 & 96 \\
\hline 3 & 12.25 & 12.25 & 10.50 & $6.6^{\mathrm{c}}$ & 15 & 5 & 80 \\
\hline 4 & 16.80 & 16.80 & 1.75 & $7.5^{\mathrm{ab}}$ & 5 & 4 & 91 \\
\hline 5 & 16.80 & 12.25 & 6.30 & $7.3^{\mathrm{ab}}$ & 5 & 0 & 95 \\
\hline 6 & 12.25 & 16.80 & 6.30 & $7.5^{\mathrm{ab}}$ & 5 & 0 & 95 \\
\hline 7 & 15.05 & 15.05 & 4.55 & $7.3^{\mathrm{ab}}$ & 5 & 4 & 91 \\
\hline 8 & 18.20 & 13.65 & 3.15 & $7.3^{\mathrm{ab}}$ & 4 & 5 & 91 \\
\hline 9 & 13.65 & 18.20 & 3.15 & $7.3^{\mathrm{abc}}$ & 4 & 2 & 95 \\
\hline 10 & 13.65 & 13.65 & 7.70 & $7.0^{\mathrm{bc}}$ & 7 & 7 & 85 \\
\hline
\end{tabular}

*Means of 55 consumers followed by the same letter in column do not differ significantly ( $>0.05)$ by the Tukey test;

$* *$ The percentages observed for categories 1 through 4 were added and termed "\% rejection", while the percentages for categories 6 through 9 were termed "\% acceptance"; category 5 was considered the indifference region ("neither liked nor disliked").

Source: Elaboration of the authors.

\section{Sensory evaluation}

The project followed the legal ethical aspects and was approved by a Committee of Ethics in Research Involving Human Subjects (UFV registration number 50704452893). The formulations were submitted to sensory tests to determine their acceptance by potential consumers. A group of fifty five juice or nectar consumers, that were not familiar with the mixed nectar of fruits flavor, aged between 20 and 50, 43 females and 12 males, committed to be available for the sensory tests. During three consecutive days, three sessions were realized to verify the acceptance of the 10 formulations. The tests were applied in individual booths, under white light. $30 \mathrm{~mL}$ samples were served monadically, in glass cups codified with three digit numbers, at $17 \pm 1^{\circ} \mathrm{C}$. The order of presentation was balanced according to the design proposed by MacFie et al. (1989). Global Impression was evaluated by using a nine categories structured hedonic scale (PERYAM; PILGRIM, 1957). For data analysis, numerical values were associated to each category, from 1= disliked it very much to $9=$ liked it very much .

\section{Statistical analysis}

The hedonic values were submitted to analysis of variance (ANOVA) and the means submitted to the Tukey test at $5 \%$ probability. All the statistical analyses were performed using the statistical program Statistical Analysis System (SAS, 2006) version 9.1

The percentages observed for categories 1 through 4 were added and termed " $\%$ rejection", while the percentages for categories 6 through 9 were termed "\% acceptance"; category 5 was considered the indifference region ("neither liked nor disliked") (Table 2).

Sensory data were also pretreated by Cluster analysis, were the similarities were calculated on the basis of the squared Euclidean distance (EVERITT; DUNN, 2001), and the Ward hierarchical agglomerative method was used to establish clusters (WARD, 1963):

$$
d_{i j}=\sqrt{\frac{\sum_{k=1}^{m}\left(X_{k}-X_{k}\right)^{2}}{m}}
$$


Where dij is the Euclidean distance; e Xik and $\mathrm{Xjk}$ are the $\mathrm{k}$ quantitative variables of $\mathrm{i}$ and $\mathrm{j}$ individuals, respectively.

Clusters data were submitted to Principal Component Analysis (PCA) using the Pearson's correlation coefficient method (normed-PCA, variance with $1 / \mathrm{n}$ ). Cluster and PCA analysis were performed using the software program XLSTAT (2005) (Addinsoft, New York, USA), version 7.5.

\section{Results and Discussion}

Table 2 presents the mean hedonic value and acceptance rate for each formulation. The formulations presented good acceptability, classified between "slightly liked it" and "liked it very much" in the hedonic scale. Formulation 2 (12.25\% cashew apple; $21 \%$ mango; $1.75 \%$ acerola) showed the highest hedonic value (7.7), but did not differ significantly by Tukey test $(p>0.05)$ from formulations 1, 4, 5, 6, 7, 8 and 9. Despite this fact, it can be observed in Table 2 that formulation 2 had the highest acceptance percentage (96\%). Formulation 3 (12.25\% cashew apple; $12.25 \%$ mango, $10.50 \%$ acerola) with the major amount of acerola pulp, showed the lowest hedonic value (6.6), but did not differ significantly from formulations 9 and 10 .

The acerola pulp contents up $6.3 \%$ (formulations $1,2,4,5,6,7,8$ and 9) presented high sensory acceptance, regardless of the proportions between cashew and mango pulps, while acerola values from $7.7 \%$ (formulation 10) showed a decrease in acceptance, with the highest percentage of notes in the rejection and indifference range (Table 2).

Similar values were found by Matsuura et al. (2004), in a study with mixed fruit nectars of papaya, passion fruit and acerola pulps. It should be noticed that the authors did not study the same fruit pulp mixed.

The nectars showed acceptance varying from "neither liked nor disliked"(5) to "liked it very much"(8) (Table 2).

The results of cluster analysis of the data can be seen in Figure 1. In the dendogram the horizontal axe indicates the level of dissimilarity, therefore lesser the distance in the horizontal axe more similar will be the concept of consumers.

Figure 1. Dendogram of dissimilarity by the Ward's method, based on the Euclidian distances between the 55 consumers of the mixed tropical fruit nectars.

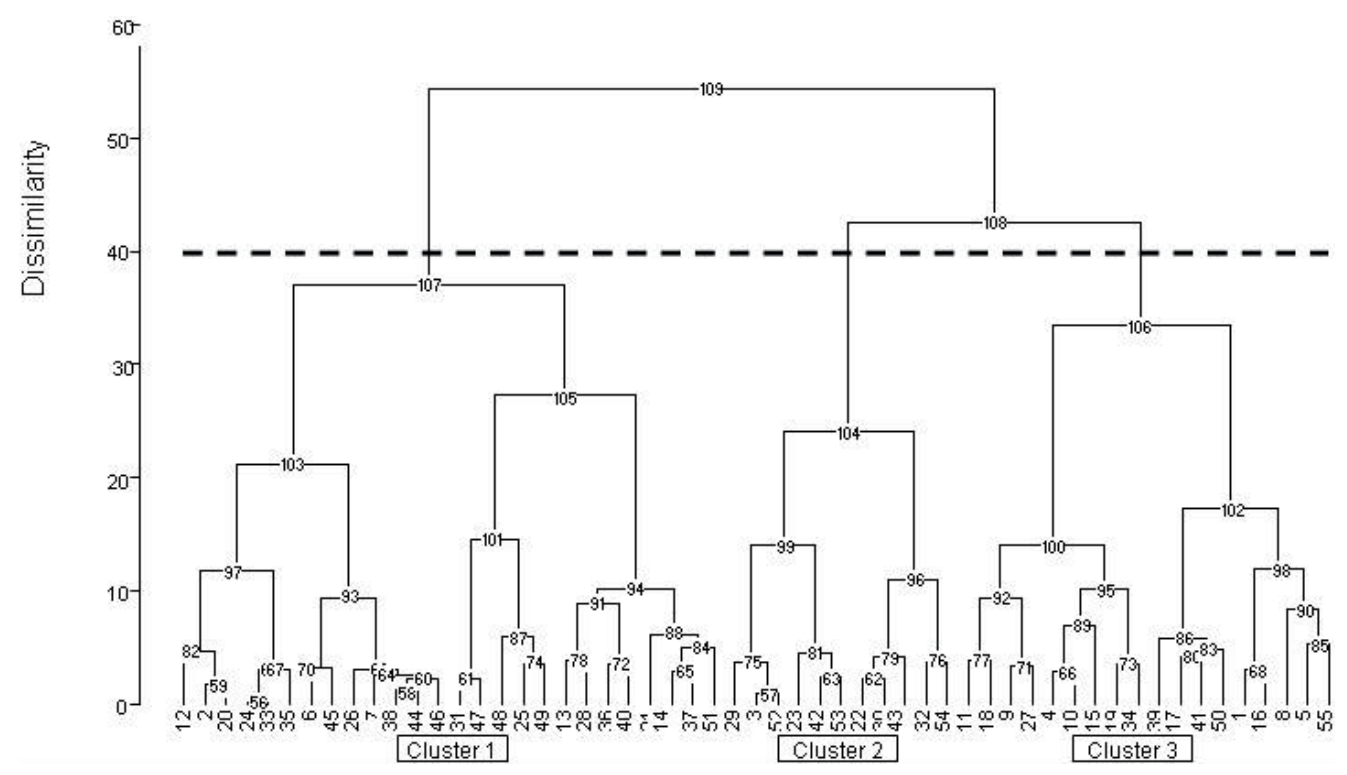

Source: Elaboration of the authors. 
The cluster analysis divided the consumer associated to the clusters 1,2 and 3, respectively in three groups, with 26, 11 and 18 consumers (Table 3).

Table 3. Cluster compositions of 55 consumers of the mixed tropical fruit nectars.

\begin{tabular}{lcl}
\hline \multicolumn{1}{c}{ Cluster } & Size & \multicolumn{1}{c}{ Potential consumers } \\
\hline Cluster 1 & 26 & $2,6, \mathbf{7}, 12,13,14,20,21,24,25,26,28,31,33,35,36,37,38,40,44,45,46,47,48,49,51$ \\
Cluster 2 & 11 & $3,22,23,29,30,32,42,43,52,53, \mathbf{5 4}$ \\
Cluster 3 & 18 & $1,4,5,8,9,10,11,15, \mathbf{1 6}, 17,18,19,27,34,39,41,50,55$ \\
\hline
\end{tabular}

In bold, nearest observation from its cluster centroid.

Source: Elaboration of the authors.

To identify the individual preferences of these clusters toward the different nectar formulations a PCA was applied to the clusters' data, which produced a multidimensional space represented by dimensions which explains the total variation among the samples. In this study it was used only the first and second dimensions, that together explained $76.5 \%$ of the data variability.

Figure 2 shows the bi-plot graphic, where the scores of the formulations were represented by points and the clusters loadings represented by vectors. Each vector indicates the direction of preference in regard to the group of samples. Therefore, each cluster was placed next to the samples of this preference.

It is clearly observed that samples 3 and 10, both with the highest acerola pulp contents were separated from the remaining ones by the second dimension (CP2) and are located in the opposite direction from all three clusters vectors, confirming that consumers preferred formulations with low contents of acerola pulp (Figure 2).

The first preference dimension (PC1) separated formulations 2 and 6 (at the right side), preferred by consumers of cluster 1 , from formulation 8 (at the left side), preferred by cluster 3 . Observing the Table 3, it can be seen that cluster 1 presented the largest number consumers (26), so it can be stated that large preference among consumers was for formulations prepared with high proportions of mango pulp. People from cluster 2 (11 consumers) liked formulation 1, with the highest cashew apple content $(21 \%)$, preferring it to formulation 8 , with also a high cashew apple content $(18,20 \%)$ but with double of acerola pulp content. The formulations 1 , 2, 6 and 8 are promising, but for different consumers groups. Of these, the formulations 2 and 6 are the most promising as they are accepted by consumers of cluster 1 and 2. The formulations 5 and 7, all with medium contents of cashew apple and mango pulps were placed near the center of the graphic, meaning that these samples were equally liked by all consumers. Similar results were found by Mostafa, Abd-El-Hady and Askar (1997) when prepared a nectar based in a mixture of $30 \%$ of mango and papaya pulps. These authors observed that the increase in mango pulp content in the mixture was also responsible for the increase in the acceptance of the attributes appearance, aroma and flavor. 
Figure 2. Principal component 1 versus component principal 2, for the clusters of consumers and formulations of mixed tropical fruit nectars, where the scores of the formulations were represented by points and the clusters loadings represented by vectors. Formulations: 1 (21\% cashew apple, $12.25 \%$ mango, $1.75 \%$ acerola), 2 (12.25\% cashew apple, $21 \%$ mango, $1.75 \%$ acerola), 3 (12.25\% cashew apple, $12.25 \%$ mango, $10.50 \%$ acerola $), 4(16.80 \%$ cashew apple, $16.80 \%$ mango, $1.75 \%$ acerola), 5 (16.80\% cashew apple, $12.25 \%$ mango, $6.30 \%$ acerola), 6 (12.25\% cashew apple, $16.80 \%$ mango, $6.30 \%$ acerola), 7 (15.05\% cashew apple, $15.05 \%$ mango, $4.55 \%$ acerola), 8 (18.20\% cashew apple, $13.65 \%$ mango, $3.15 \%$ acerola), 9 (13.65\% cashew apple, $18.20 \%$ mango, $3.15 \%$ acerola), 10 (13.65\% cashew apple, $13.65 \%$ mango, $7.70 \%$ acerola)).

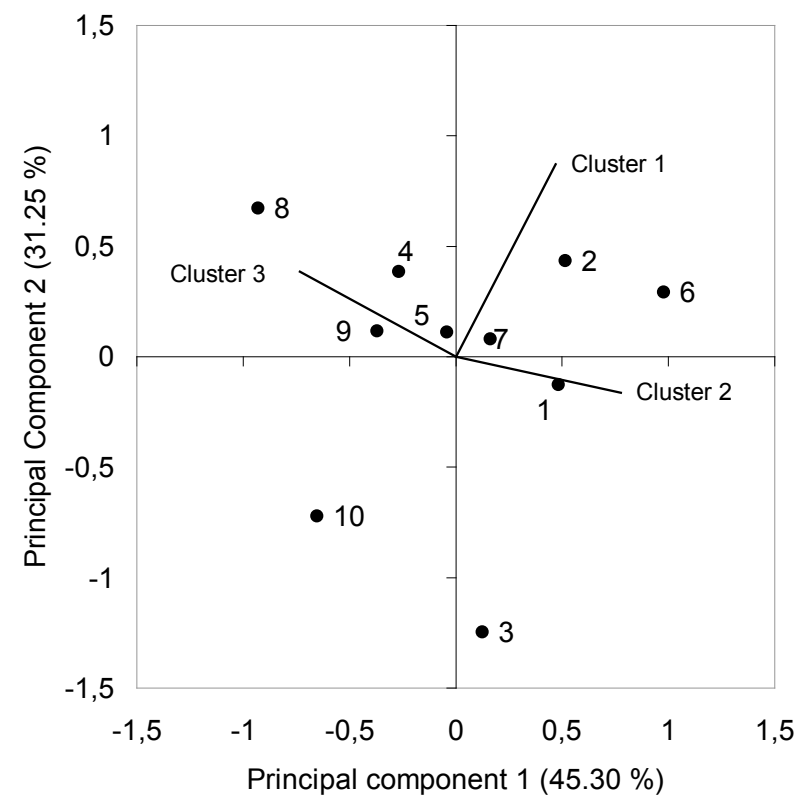

Source: Elaboration of the authors.

In a study on mixture design (cashew apple, passion fruit, papaya, guava and acerola) of mixed tropical fruit nectar, Sousa et al. (2007) observed a decrease in the global impression scores with the increase of acerola and passion fruit pulp contents in the formulations. Such behavior towards the addition of acerola juice was also verified by Matsuura and Rolim (2002) when developing different formulations with whole pineapple juice, ranging from 40 to $47.5 \%$, added to whole acerola juice at concentrations ranging from 2.5 to $10 \%$, aiming to enrich the product with vitamin $\mathrm{C}$. The authors observed that the flavor was the limiting factor, with good acceptance up to $7.5 \%$ of acerola juice added to the mixture. Different results were observed by Matsuura et al. (1999), who concluded, using response surface designs, that a mixture of mango nectar with acerola juice had its optimum acceptance region close to $20 \%$ of acerola juice and $80 \%$ of mango juice. The results of the PCA showed a segmentation of consumers toward the formulations, forming groups that had different preferences, confirming that the simple arithmetic means of hedonic values can compromise the choice of a product by canceling the effects of segmentations present in the affective sensory data.

\section{Conclusions}

The results indicated a greater acceptance for fruit nectars with cashew apple and mango pulp, independent of the proportions between them, and above $7.7 \%$ of the acerola pulp content in the formulation of nectars, it counts down in the overall acceptance.

Through the cluster analysis of consumers and later analysis of PCA of these results, it could be observed more clearly the segmentation of groups of consumers which preferred differentiated formulations.

\section{Acknowledgments}

Conselho Nacional de Desenvolvimento Científico e Tecnológico (CNPq) for granting a doctorate and research scholarships and funding through the Universal Edital CNPq no 019/2004.

\section{References}

BEEBE, K. R.; PELL, R. J.; SEASHOLTZ, M. B. Chemometrics: a practical guide. New York: Wiley, 1998. 360 p.

BRITO, E. S.; ARAUJO, M. C.; LIN, L.; HARNLY, J. Determination of the flavonoid components of cashew apple (Anacardium occidentale) by HPLC-DAD-ESI/MS. Food Chemistry, London, v. 105, n. 3, p. 1112-1118, 2007. 
DAHL, T.; NAES, T. Outlier and group detection in sensory panels using hierarchical cluster analysis with the procrustes distance. Food Quality and Preference, Barking, v. 15, n. 3, 195-208, 2004.

DEMBITSKY, V. M.; POOVARODOM, S.; LEONTOWICZ, H.; LEONTOWICZ, M.; VEARASILP, S.; TRAKHTENBERG, S.; GORINSTEIN, S. The multiple nutrition properties of some exotic fruits: Biological activity and active metabolites. Food Research International, Barking, v. 44, n. 7, p. 1671-1701, 2011.

EVERITT, B. S.; DUNN, G. Applied multivariate analysis. $2^{\text {nd }}$ ed. London: A Hodder Arnold Publication, $2001.352 \mathrm{p}$.

FAO/WHO. Codex alimentarius. In: Report of the fourth session of the ad hoc codex intergovernmental task force on fruit and vegetable juices. Fortaleza, CE: FAO/WHO, 2005. p. 1-46.

FARAONI, A. S.; RAMOS, A. M.; GUEDES, D. B.; OLIVEIRA, A. N.; LIMA, T. H. S. F.; SOUSA, P. H. M. Desenvolvimento de um suco misto de manga, goiaba e acerola utilizando delineamento de misturas. Ciência Rural, Santa Maria, v. 42, n. 5, p. 911-917, 2012.

JOHNSON, R. A.; WICHERN, D. W. Applied multivariate statistical analysis. $5^{\text {th }}$ ed. Prentice Hall: Englewood Cliffs, 2002. 767 p.

KUBO, I.; MASUOKA, N.; HA, T. J.; TSUJIMOTO, K. Antioxidant activity of anacardic acids. Food Chemistry, London, v. 99, n. 3, p. 555-562, 2006.

LIMA, A. S.; MAIA, G. A.; SOUSA, P. H. M.; PRADO, G. M.; RODRIGUES, S. Storage stability of a stimulant coconut water acerola fruit juice beverage. International Journal of Food Science and Technology, Barking, v. 44, n. 7, p. 1445-1451, 2009.

LIMA, V. L. A. G.; MELO, E. A.; MACIEL, M. I. S.; PRAZERES, F. G.; MUSSER, R. S.; LIMA, D. E. S. Total phenolic and carotenoid contents in acerola genotypes harvested at three ripening stages. Food Chemistry, London, v. 90, n. 4, p. 565-568, 2005.

MACFIE, H. J.; BRATCHELL, N.; GREENHOFF, K.; VALLIS, I. V. Designs to balance the effect of order of presentation and first-order carry-over effects in hall tests. Journal of Sensory Studies, Westport, v. 4, n. 2, p. 129-148, 1989.

MATSUURA, F. C. A. U.; FOLEGATTI, M. I. S.; CARDOSO, R. L.; FERREIRA, D. C. Sensory acceptance of mixed nectar of papaya, passion fruit and acerola. Scientia Agricola, Piracicaba, v. 61, n. 6, 604608, 2004.
MATSUURA, F. C. A. U.; FOLEGATTI, S. I. S.; CARDOSO, R. L.; SILVA, M. A. A. P. Otimização da aceitação de néctar de manga enriquecido com acerola através de metodologia de superfície de resposta e mapa de preferência. In: SIMPÓSIO LATINO AMERICANO DE CIÊNCIA DE ALIMENTOS, 3., Campinas. Anais... Campinas: Sociedade Brasileira de Ciência e Tecnologia de Alimentos, 1999. p. 210.

MATSUURA, F. C. A. U.; ROLIM, R. B. Avaliação da adição de suco de acerola em suco de abacaxi visando à produção de um "blend" com alto teor de vitamina C. Revista Brasileira Fruticultura, Jaboticabal, v. 24, n. 1, p. 138-141, 2002.

MOSTAFA, G. A.; ABD-EL-HADY, E. A.; ASKAR, A. Preparation of papaya and mango nectar blends. Fruit Processing, Chicago, v. 7, n. 5, p. 180-185, 1997.

MYERS, R. H.; MONTGOMERY, D. C. Response surface methodology: process and product optimization using designed experiments. New York: Wiley, 2002. 824 p.

PEREIRA, A. C. S.; SIQUEIRA, A. M. A.; FARIAS, J. M.; MAIA, G. A.; FIGUEIREDO, R. W.; SOUSA, P. H. M. Desenvolvimento de bebida mista à base de água de coco, polpa de abacaxi e acerola. Archivos Latinoamericanos de Nutricion, Caracas, v. 59, n. 4, p. 441-447, 2009.

PERYAM, D. R.; PILGRIM, P. J. Hedonic scale method for measuring food preferences. Food Technology, Chicago, v. 11, n. 1, p. 9-14, 1957.

POOVARODOM, S.; HARUENKIT, R.; VEARASILP, S.; NAMIESNIK, J.; CVIKROVA, M.; MARTINCOVA, O.; EZRA, A.; SUHAJ, M.; RUAMSUKE, P.; GORINSTEIN, S. Comparative characterisation of durian, mango and avocado. International Journal of Food Science and Technology, Oxford, v. 45, n. 5, p. 921 929, 2010.

QANNARI, E. M.; VIGNEAU, E.; LUSCAN, P.; LEFEBVRE, A. C.; VEY, F. Clustering of variables, application in consumer and sensory studies. Food Quality and Preference, Barking, v. 8, n. 5,6, p. 423-428, 1997.

RAMOS, A. M.; SOUSA, P. H. M.; BENEVIDES, S. D. Tecnologia de industrialização da manga. In: ROZANE, D. E.; DAREZZO, R. J.; AGUIAR, R. L.; AGUILERA G. H. A.; ZAMBOLIM, L. (Ed.). Manga: produção integrada, industrialização e comercialização. Visconde do Rio Branco: Suprema Gráfica e Editora Ltda, 2004. p. 571-604.

SAS Institute Inc. SAS User's guide: version 9.1, Cary, NC: SAS Institute, 2006. 
SHARAF, M. A.; ILLMAN, D. L.; KOWALSKI, B. R. Chemometrics. New York: John Wiley \& Sons, 1986. $332 \mathrm{p}$.

SOUSA, P. H. M.; MAIA, G. A.; AZEREDO, H. M. C.; RAMOS, A. M.; FIGUEIREDO, R. W. Storage stability of a tropical fruit (cashew apple, acerola, papaya, guava and passion fruit) mixed nectar added caffeine. International Journal of Food Science and Technology, Oxford, v. 45, n. 10, p. 2162-2166, 2010.
SOUSA, P. H. M.; MAIA, G. A.; AZEREDO, H. M. C.; SOUSA FILHO, M. S. M.; GARRUTI, D. S.; FREITAS, C. A. S. Mixed tropical fruit nectars with added energy components. International Journal of Food Science and Technology, Oxford, v. 42, n. 11, p. 1290-1296, 2007.

WARD, J. H. Hierarchical grouping to optimize an objective function. Journal of the American Statistical Association, New York, v. 58, n. 301, p. 236-244, 1963.

XLSTAT - PRO. User's guide. Addinsoft, New York, USA, Version 7.5. 2005. p. 1-104. 
